\title{
Translation
}

Noroz Hayat

\section{Yes, Dear Mother, Your Son is Back in the Mountains*}

https://doi.org/10.33063/diva-434235

Introduction: Noroz Khan, better known by his pen name Noroz Hayat, was born on 1 February 1989 in Khairabad village, close to Turbat, Kech District, Balochistan, Pakistan. He received a BA with a triple major in Balochi, Sociology and Political Science from the Atta Shad Degree College in Turbat, and an MA in Social Work from the University of Karachi, where he finished his studies in 2013. Noroz Hayat is married and has two children.

During his college years, Noroz Hayat became a member of the Baloch Students Organization which, in addition to organizing Baloch students, also has a political agenda. ${ }^{1}$ However he became increasingly interested in human rights, and has recently been active in the Human Rights Council of Balochistan, "a non-profit and non-partisan human rights group in Balochistan, Sweden, UK and France." ${ }^{2}$ The main purpose of this organization is to collect information and publish reports on human rights violations in Balochistan, in order to make international human rights organizations aware of the dire situation in the region.

During his time in Karachi, Noroz Hayat worked as a volunteer at the Syed Zahoor Shah Hashmi Reference Library, where he was a member of the library's executive committee. His duties included keeping track of new books being published in Balochi and acquiring them for the library, organizing literary and cultural events, and facilitating classes in Balochi run on a private basis. Between 2014 and 2015, after graduating, he worked as a programme associate at the Health and Nutrition Development Society (HANDS), based in Karachi. ${ }^{3}$

In 2015 Noroz Hayat left Pakistan for the USA, and he currently lives in Connecticut. Since arriving in the USA, Noroz has written on social, political and human rights issues, in both Balochi and English, with his writings mainly being published in two web-based magazines, Balochistan Times ${ }^{4}$ and Balochistan Affairs. ${ }^{5}$

When asked what motivated him to start writing, Noroz Hayat says that shortly after going into exile he felt a strong urge to spread the word about the present situation in his homeland, in order to be a voice for those who have no voice in the international arena. He also began composing fictional pieces expressing the feelings of people in exile, which can include a sense of alienation and nostalgia. ${ }^{6}$

In an article published in Balochistan Times on 19 September $2019,{ }^{7}$ Noroz Hayat writes about his youth and education, and how he became interested in social and political issues. He also shares personal experiences of the "kill-and-dump" strategy that is presently being carried out in Balochistan. ${ }^{8}$

1 https://en.wikipedia.org/wiki/Baloch_Students_Organization (Retrieved 2020-08-18)

2 https://hrcbalochistan.com/about/ (Retrieved 2020-11-24)

3 http://hands.org.pk/live/ (Retrieved 2020-11-24)

4 https://balochistantimes.com/ (Retrieved 2020-11-24)

5 https://www.balochistanaffairs.com/ (Retrieved 2020-11-24)

6 Personal communication, 24 November 2020.

7 https://balochistantimes.com/why-i-left-home-the-story-of-a-baloch-refugee/ (Retrieved 2020-11-24)

8 See e.g. https://unpo.org/article/19046 (Retrieved 2020-11-24)

\footnotetext{
* Translated, with introduction, by Carina Jahani, Department of Linguistics and Philology, Uppsala University, Sweden, E-mail: carina.jahani@lingfil.uu.se, in collaboration with Noroz Hayat, Connecticut, USA, E-mail: norozhayat@yahoo.com 
At the very end of this article, he writes that he has not been back to his native village since June 2014. The reader can easily sense his strong attachment to his native village, his homeland.

This attachment to a homeland is also the theme of the story translated here, Yes, Dear Mother, Your Son is Back in the Mountains, which tells of a person who is spending his life far from his native land, and who constantly longs to return. It is inspired by the life story of Sajid Hussain, another Baloch intellectual and literary activist from Kech District who in his youth moved to Karachi to pursue his education and later worked as a journalist there. Sajid Hussain was forced into exile a few years before Noroz Hayat. Noroz's story contains several subtle allusions to an interview with Sajid ${ }^{9}$ and to Sajid's story Facing Exile, Facing Taunts. ${ }^{10}$

But the story that follows could also be that of anyone who has left his or her homeland, be it in search of a career or at least a livelihood, to seek a safe haven from oppression, torture and war, or for any other reason, and who constantly longs to return to "the Mountains", the place where he or she truly belongs.

This distress of his was increasing day by day. It felt like a century since he had left his homeland, the Mountains. That homeland, that old country, and the people who live there, even though they were struggling with various hardships these days, they were the ones who had given him an identity. $\mathrm{He}$ wondered how they were doing now, after so much misery and destitution.

He had actually left his homeland long ago, in his youth. But not for reasons of exile or migration abroad. He went to live in a big city to study. But his inner being constantly missed the moonlight of the late nights in the Mountains. He would find himself longing to sit atop Chief Hasan's berm absorbing the scenery of his village, or to play cards at the Sangin roundabout at dusk.

So, packing his worn-out little bag he would head back to the Mountains the next day. After completing his studies he got a job in the city, and although he was not a physically active person, whenever his yearning for the Mountains became too strong, he would travel home. Some of the time he was in the big city, some of the time in the Mountains. Whenever he was travelling, he thought to himself that if his journey was just a bit longer, he would immediately break with his beloved Mountains, because he really didn't like all these long, drawn out and tiring journeys back and forth.

He did not really leave his homeland for good until the year when there was a huge flood in the Mountains. This merciless flood devastated the Mountains completely. It swept away everything in its path, the domestic animals, houses and farming lands of the people living there. The torrents of the big river also took an uncle, a cousin and some of his friends.

In fact there was always hunger and poverty in the Mountains. People were poor and needy there. Their greatest struggle was to find something to eat for the day, and they subsisted on the hope that God would help them find something tomorrow. Having eaten some little something, they carried on as best they could. If these little somethings were to run out, then a neighbour, a friend or a relative would lend them some edibles. And if no one could lend them anything to eat, then surely a brother, a grown son or an elder of the family would find the courage to go to a foreign land, take a menial job, and feed a mother, a father, a child and a wife.

$\mathrm{He}$, too, left his homeland and became a wanderer in search of a livelihood, hoping to save himself from the poverty and destitution of the Mountains. With the ups and downs of living abroad he also became detached from his motherland, his language and his culture. The land was actually nothing you could call a land. For a long time after leaving, he had no desire to return. The language had been neglected for centuries, and the sons of the Mountains had not done such a great job of saving it ei-

9 https://www.youtube.com/watch?v=Troo9srFxMY (In Balochi) (Retrieved 2020-05-10)

10 See https://doi.org/10.33063/diva-419088 (Retrieved 2020-09-24) 
ther. Even worse, the Government had done what it could to eradicate it. Therefore he never had any great desire to read and write his own language. Also, when you resort to going abroad to find a job, you have to wear their kind of clothing to be able to work in their companies and offices. As a result he had become so used to the dress of others that he had never since worn the dress of his own culture.

For 37 years he had lived in foreign lands, never settling down. His sojourn in Arab countries, Africa and the West had worn him out so much that he looked like a piece of wood eaten by termites. At this stage he had nothing left but feeble emotions.

But the emotions were still there. He did have a motherland, he did have a language, he did have a people and his people did have a soil. They had been living on this soil for thousands of years, but now it was afflicted by war. The sons of the land were being killed. Some were exiled from their land by force. Some were bribed, and others still were threatened to keep them quiet about the violence of the regime. These emotions were constantly consuming him like a fire, and the flames of this inner fire compelled him all the more strongly to return to his land: "It is time to return home. Enough with all this exile!"

Without telling anyone, neither his friends in exile nor his family in the Mountains, one day he returned to his motherland with nothing but a pair of empty hands. Before returning, he had strug gled in his heart: "Should I tell my family and friends that I've had enough of this exile? That I want to return to my motherland, I want to speak my own language, I want to wear my own clothes? Enough depending on foreigners. There is no place like home! It is better for me to seek refuge in my motherland, however poor and destitute it may be."

But all he did was smile to himself and say: "No, it is better not to trouble anyone. Just as I went into exile unannounced, I will keep quiet about my return and not bother anyone. I will go and lie down right there in the Mountains and take some rest on my land, on my soil."

The thoughts that had distressed him in exile proved true: the Mountains had indeed changed a lot by now. These alleys, that township, this bazaar, those villages - their appearance had completely changed. Molla Patomah had left the village before the war and her huge compound had fallen into ruins. Chief Hasan and the people of Nodan village had abandoned their habitation in the Mountains after the war, and left it to desolation. But not everything had changed - the breeze at dawn, the sunset, the duststorms, the moonlight, the scorching heat, the season of the date harvest from the earliest dates to ripen to the very end of the season, and the moist smell after the first rain of the year were all exactly like they used to be.

Yes, dear mother, your son is back in the Mountains! ${ }^{11}$

11 The translation of Noroz Hayat's short story Yes, Dear Mother, Your Son is Back in the Mountains was first published in Balochistan Times on 20 December 2020, see https://balochistantimes.com/back-in-the-mountains (Retrieved 2020-12-20) 